\title{
Motivation for Excellence in Forestry Research ${ }^{1}$ \\ J. Burley ${ }^{2}$
}

\begin{abstract}
Forestry cannot be considered as a single commodity and research is not a homogeneous activity. Forestry and its research are carried out in various topics, stages and types, locations, institutions, ecological zones, and stage of country development. Excellence in research can apply to individual scientists, specialist groups, whole institutions, networks of institutions, and the managers of any of these.

There is thus a multi-dimensional matrix within which to identify appropriate motivations for excellence. Research excellence itself may have different implications for scientists, science managers, and financiers and policy-makers. Motivating forces (incentives) are also varied but can be summarized simplistically as fame and fortune. However, other factors may be equally important to individuals (security, career structure, personnel policies, creative freedom, relevance of research not just fashionableness, resources, managerial methods and general working environment).

The structure and composition of the International Union of Forestry Research Organizations (IUFRO) is described and a summary of Canadian activities in IUFRO is included.
\end{abstract}

\section{Résumé}

La foresterie ne peut être considérée comme un seul produit de base et la recherche ne constitue pas une activité homogène. la foresterie et la recherche dans ce domaine couvrent divers sujets, divers stades de développement et types, divers endroits, institutions, zones écologiques, et étapes de développement d'un pays. L'excellence en recherche peut s'appliquer à chaque chercheur, aux groupes de spécialistes, aux institutions entières, aux réseaux d'institutions, et aux gestionnaires de ces institutions.

Le tout forme donc une matrice multi-dimensionnelle à partir de laquelle on peut identifier les motivations appropriées pour l'excellence. L'excellence en recherche a par elle-même différentes implications pour les scientifiques, les gestionnaires scientifiques, les financiers et les politiciens. Les forces de motivation (les incitatifs) sont aussi variés mais peuvent se résumer simplement comme étant la gloire et la fortune. Cependant. d'autres facteurs peuvent être également aussi importants pour certains individus (sécurité, cheminement de carrière, politiques de personnel, liberté d'expression, la pertinence de la recherche et pas seulement la vogue, les ressources, les méthodes de gestion et l'environnement globa! de travail).

La structure et la composition de l'Union internationale des instituts de recherche forestière (IUFRO) sont décrites et un sommaire des activités canadiennes de l'IUFRO est présenté.

Cette présentation a été sollicitée par le Comité organisateur de l'Institut forestier du Canada dans le cadre de l'Assemblée annuelle du 20 août 1990, mais a été aussi présentée en tant que substitution de dernière minute pour un exposé thématique lors du 19ème Congrès de l'IUFRO, qui a eu lieu à Montréal, le 7 août 1990. Au cours du congrès, l'auteur, a été élu viceprésident des programmes de l'Union.

\section{Forestry and the Need for Research}

\section{The role of trees and forests in development}

Throughout the world there is an increasing awareness of the role of trees and forests in sustaining financial, economic, social and environmental development. Forests and their constituent individual trees provide a wide range of products and benefits for mankind and his domestic animals including:

1. solid wood for use as poles or sawtimber for construction and furniture

2. solid or processed wood for fuel (firewood, charcoal, fluid fuels)

3. comminuted wood for pulp, paper, boards

4. chemical products and extractives derived from wood or other tree parts

5. human food

6. animal fodder

7. environmental modification including shade, wind-shelter, water-flow moderation, soil stabilization and improvement

${ }^{1}$ This paper was invited by the Organizing Committee of the Canadian Institute of Forestry for presentation at the Annual Meeting on 20 August 1990 but it was also presented as a last-minute substitution for a keynote speech at the 19th IUFRO Congress, Montreal, on 7 August 1990. At the Congress the author was elected as Vice-President for Programmes of the Union. ?Oxford Forestry Institute. Plant Sciences Department. Oxford University, South Parks Road, Oxford, OXI 3RB, England.
8. socioeconomic benefits including import substitution, foreign exchange earning, individual income and security. diversity and risk avoidance, improved human and animal health and nutrition, improved drainage and sanitation

9. maintenance of the genetic diversity of plant and animal species indigenous to the forest that have present or potential future use

\section{Trees in land use systems}

A large number of land use systems involve trees which can be summarized as five general forestry applications and six specific agroforestry applications:

1. protection forestry, land reclamation and rehabilitation

2. natural vegetation management

3. industrial plantations

4. community woodlots

5. farm woodlots

6. trees in cropland and mixed intercropping

7. alley farming, alley cropping, hedgerow intercropping

8. linear planting on boundaries, roads, etc.

9. shelterbelts and windbreaks

10. sequential cropping (including taungya, shifting cultivation) 11. silvopastoral systems

Many of the services and benefits derived from trees in these land use systems are difficult to quantify in productive 
or economic terms yet are of fundamental importance for future development. Since they are difficult to quantify, it is equally problematical to assign research priorities to them.

Scientists, administrators, politicians and the public are assailed daily with a vast output from the technical and lay media showing or claiming the links between forests or deforestation and global climate change, soil and water conservation, and genetic biodiversity. Although this should be advantageous for the forestry profession (and indeed there is certainly an increasing flow of government funding for various aspects of forestry), we should temper our enthusiasm with three considerations.

\section{Constraints on Forestry and Research}

\section{Long-term investment}

Forestry is currently fashionable but by nature it is a longterm activity and long-term investments are not attractive to politicians who generally have a short-time horizon (the next election), to industrial investors who require short-term returns, nor to donor agencies who seek social and environmental benefits in developing countries that cannot be easily quantified. For all of these actors security can be obtained only if there is a long-term commitment by governments to logical and integrated development and land use policies.

\section{Academic respectability}

Forestry has suffered for generations from the "dirtyboot" syndrome. Academics, learned societies and research councils have commonly regarded forestry (and agriculture) as too applied to merit serious consideration for support or acclaim. The fact that forestry education and research have more measurable, generally positive effects than many other disciplines is often ignored. Even now, as the importance and fate of the world's forests are placed firmly in the public eye, it is becoming progressively more difficult to convince the academic world of the necessity of supporting research and education in the social, economic and technical aspects of forestry. (I am glad to see that this does not appear to be the case in Fredericton where the university campus houses a forestry centre involving university, provincial, federal and industrial units.) There is a tendency to view the future problems in the light of new technological solutions of the brave new world rather than capitalizing on less glamorous but more immediately productive systems.

\section{Information}

There is a general lack of hard information and, even worse, a lack of appreciation of the information that already exists, on the links between forests, trees, environment and development. The lack of appreciation of existing knowledge requires financial and professional resources to conserve, compile and disseminate the information. The lack of information on some topics requires new research to answer the specific questions being posed by the media, the public, politicians and administrators.

Like any other investment, research must be seen to be effective and this requires not only good research per se but effective dissemination and application of the results of the research. The Oxford Forestry Institute houses the western world's library of deposit for forestry and related literature; in collaboration with the CABI at Wallingford, it attracts, stores and makes available the bulk of the world's published literature and much "grey" material. The CABI itself abstracts the material into Forestry Abstracts, Forest Products Abstracts and Agroforestry Abstracts and enters it into the international database systems such as DIALOG. We have recently obtained funds from the UK Government's Overseas Development Administration to produce a CD-ROM (Compact Disc - Read Only Memory) containing the complete abstracts published by CABI since 1939; the hardware, software and the searchable database itself should be available by 1992 .

Recognizing that considerable information is already available and that the wheel does not need to be continually reinvented, this paper addresses the issues of obtaining excellence in research itself.

\section{Forestry Research Structure}

\section{The research-development-application continuum}

For many of these systems systematic research is undoubtedly needed to maximize the sustainable production of all required benefits. However, it must be stressed that research should not be conducted in a vacuum nor for the benefit of the researcher. There is a clear need to identify the true beneficiaries of land and forest benefits and to direct research to meeting the requirements of the ultimate beneficiary rather than of the policy-maker or professional manager. Research should be continually monitored and adjusted by feed-back from the beneficiaries as indicated in Figure 1. There is a continuum from basic research through strategic, applied and adaptive research, to the extension and education systems, and on to widespread application of technologies.

\section{Forestry research topic priorities}

In many countries there is a need for research in technical, biological, social, environmental and institutional factors, many of which are inter-dependent. Thus forestry and its research cannot be considered as a single discipline; it is not analogous to the crop orientation of the International Agricultural Research Centres of the Consultative Group for International Agricultural Research (CGIAR) which deal, for example, with the total improvement and management of maize or rice.

The topics for which research is needed in developing countries have been identified by various fora and expert groups throughout the decade of the 1980s including the World Bank, CGIAR (through its Technical Advisory Committee), World Resources Institute, the so-called Bellagio I and II meetings, FAO, Oxford Forestry Institute (for anglophone Africa) and others. (A list of further reading material is appended to this paper.) There has been broad agreement that the main research areas for developing countries include the following:

1. natural forest conservation and management

2. trees in farming systems

3. tree breeding and intensive forestry

4. forest products utilization

5. policy and socio-economic analysis

These same topics receive recognition in the intensive review for the USA conducted by the US National Research Council (1990) and many of the topics occur in the review of Canadian research reported in special issues of The Forestry Chronicle (Vol. 66, No. 2, 1990) and the Canadian 
Policy and objectives $\rightarrow$ Land use systems $\rightarrow$ Products, benefits (products, benefits)
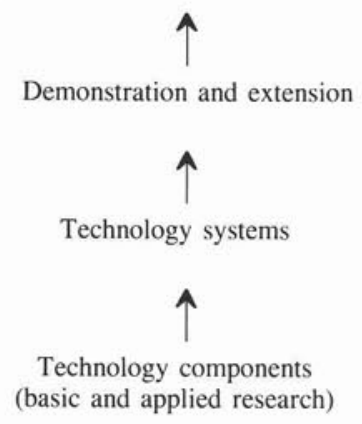

$$
\uparrow_{\text {Research }}
$$

(for innovation or improvement of existing technologies)

\section{个 \\ RESEARCHERS}

Figure 1. Relationship of beneficiaries of tree planting to policy, management and research

Journal of Forest Research (Vol. 20, No. 4, 1990) both published in time for the 19th IUFRO Congress.

Such agenda are commonly identified, especially in tropical countries, by external specialists who may not be aware of the social and institutional framework within which forestry operates for a given country. Research, and indeed forestry development, may be driven by fashion or by the political or economic needs of the financier rather than by the real target beneficiaries. As stressed above, there is an urgent need to recognize the relationships and feed-back mechanisms between policy-makers, land managers, researchers and the ultimate beneficiaries of land (Figure 1).

\section{Stages and types of forestry research}

Research is often seen as an end in itself both by researchers and by research managers; clearly this leads to irrelevant research and a waste of resources. Research is part of a continuum from research through development to general application; excellent research is of no value unless its results can be implemented in practice or have impact on land use policy or social structure and development.

The major stages are illustrated in Table 1 which shows the objectives of each phase (the dominant research mode), the main location and the primary collaborators in research at each stage.

\section{Locations and institutions for research}

Depending on the problem and research method, forestry research can be carried out in laboratories, research stations, on farms and in planted or natural forests. The aptitude, skill and training of appropriate research workers and support staff clearly vary among these. Frequently in-farm and in-forest research has a significant institutional and sociological component that is frequently absent from traditional forestry education, training and research institutions.

Research also has to take account of ecological zonal differences within countries and site specificity of results within zones. The current debate of the future support for international forestry research through the CGIAR system addresses inter alia those topics that can be centralized at one or two locations for the good of all, those topics that have zonal application, and those that require site-specific research and application.

Although there are obvious differences between developed and developing countries in capability and capacity for research, all can benefit from interaction among countries and among institutions within countries. Table 2 summarizes the stages of research, the contributors to it, and the users of research results.

Table 1. Stages, locations and cooperation in research

\begin{tabular}{llll}
\hline $\begin{array}{l}\text { Dominant } \\
\text { research } \\
\text { phase }\end{array}$ & $\begin{array}{l}\text { Dominant } \\
\text { research } \\
\text { mode }\end{array}$ & $\begin{array}{l}\text { Primary } \\
\text { research } \\
\text { location }\end{array}$ & \multicolumn{1}{c}{$\begin{array}{c}\text { Research } \\
\text { research } \\
\text { cooperation }\end{array}$} \\
\hline BASIC & New understanding & $\begin{array}{l}\text { In laboratories of advanced } \\
\text { research institutions }\end{array}$ & $\begin{array}{l}\text { Collaboration with advanced research } \\
\text { laboratories }\end{array}$ \\
STRATEGIC & Technology generation & $\begin{array}{l}\text { Mainly at research stations; tech- } \\
\text { nical feasibility }\end{array}$ & $\begin{array}{l}\text { Advanced laboratories with NARS } \\
\text { key research sites representatives of } \\
\text { major constraints or environments }\end{array}$
\end{tabular}

APPLIED Technology refinement

ADAPTIVE Technology synthesis and evaluation in target environments

\section{Development}

At research stations and on-farm, mainly researcher-managed; technical, managerial and economic evaluation

On-farm with farmer involvement and broader socioeconomic and impact analysis
Advanced laboratories in collaboration with many NARS at national sites; research linkages facilitated through networks

In many countries and at many sites, with major initiative taken by NARS; supported by international networks

\section{Application}

Extension training, information, financial and material support

${ }^{1}$ NARS $=$ National Agricultural Research Systems. 
Table 2. Contributors and users of the research-development-application continuum.

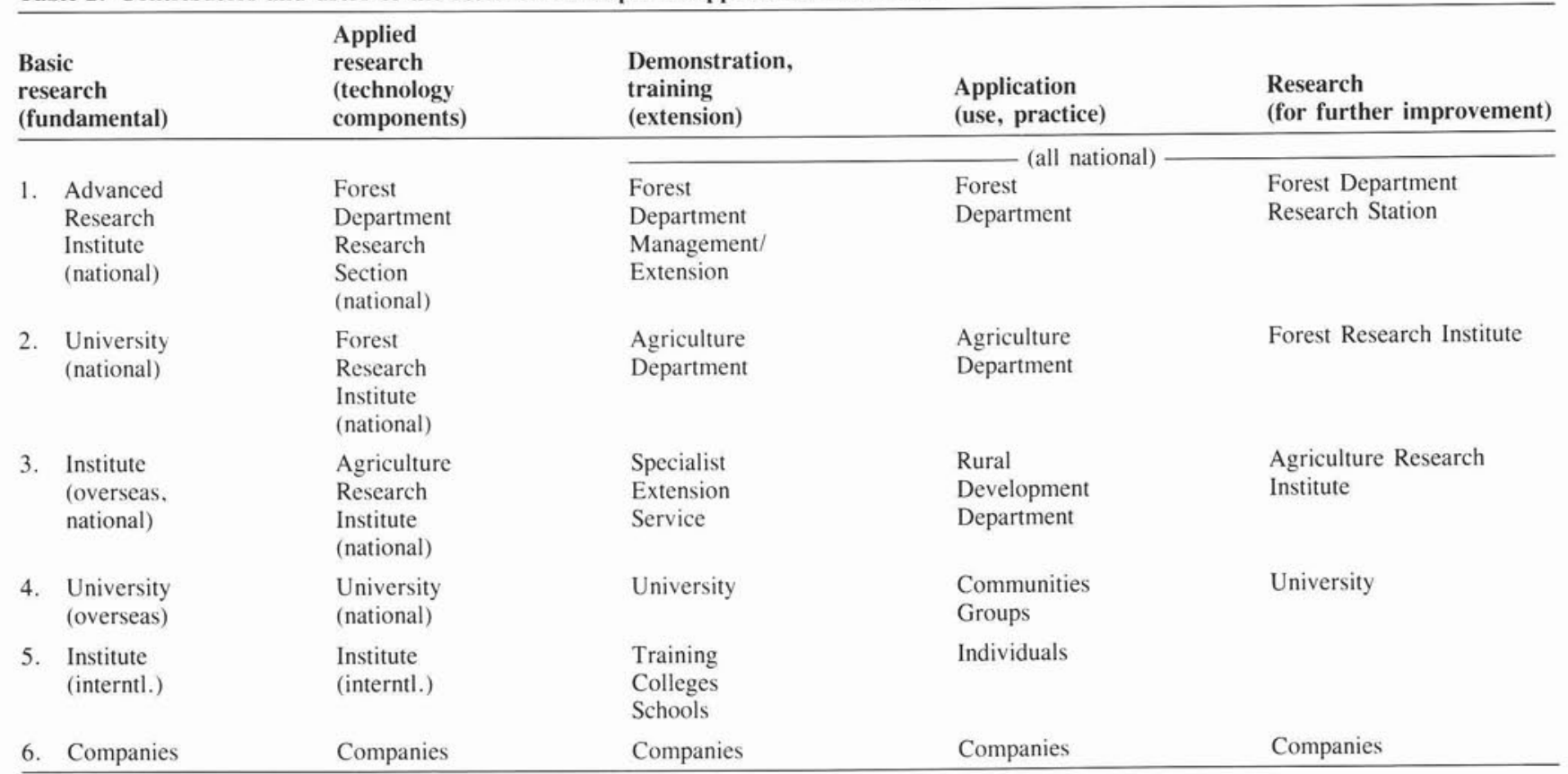

Desirability, frequency and cost-effectiveness vary with column, subject and country.

\section{Excellence in Research}

\section{Applications}

The Concise Oxford English Dictionary defines excellence as "surpassing merit; thing in which person etc. excels" while excel is defined as "surpass; be pre-eminent". This superiority clearly has different applications to individual scientists, specialist groups of scientists, whole research institutions, networks of institutions, and the managers of any of these. Together with the factorial arrangement of topics, stages, locations and institutions described above, there is thus a multidimensional matrix within which to recognize excellence and to seek appropriate motivations for attaining it.

\section{Implications}

The concept of excellence may have different implications for the people involved in research.

Individual scientists may recognize excellence (in themselves or in others) by the discovery of new and valuable information, the publication of research results in peerapproved media, or perhaps the development or use of the latest equipment and methods. (Too often research managers and financiers receive requests from scientists for purchase of the latest equipment or facilities without having a clear scientific target defined.)

Research excellence as seen by a science manager may be judged by the coherence of specialist groups within an institution, their flexibility and willingness to interact with other individuals or groups, the timely reporting and meeting approved targets by individuals or groups and the minimization of personnel problems within the institution.

For financiers and policy-makers research excellence is seen essentially as value for money in relation to the original objectives; this requires the research manager to establish rational planning and monitoring procedures. Results of research should have wide applicability and the possibility of commercialization through patenting (especially for commercial organizations).

\section{Motivations}

Incentives to attain excellence obviously vary throughout the matrix of factors described earlier. However, for individual scientists and, to a large extent, for individual research managers, the motivating forces can be crudely summarized as fame and fortune.

Fame includes reputation among scientific peers, professional colleagues and superiors; in addition for some scientists reputation among government officers or the media and public may be important and should be recognized by the astute manager.

Fortunes are rarely made in forestry research, particularly among government and academic services; however, fortune here may be taken to include several other factors besides salary and direct or indirect financial benefits such as pensions and medical insurance. To the scientist and manager great importance is attributable to employment and personal securities and a career structure. In developing countries particularly, but not exclusively, research ranks low in government and forest department priorities; it is usually reduced first if financial restrictions are imposed and individuals often are unable to pursue a career in research while still retaining promotional prospects.

Although scientists generally value the opportunity for creative freedom they also enjoy satisfaction in conducting research that has direct relevance to development problems, not just that which is driven by fashion or financier's wishes. Above all research workers seek adequate resources to pursue their topic (staff, equipment, land and operating costs) within an environment of constructive, sympathetic and efficient personnel management. 


\section{Conclusions}

Government forest services and many industrial forestry enterprises commonly place little emphasis on research; it is difficult to obtain estimates of expenditure by all agencies financing research in any given country but a study by the two Vice-Presidents-elect of IUFRO for British Commonwealth countries showed that research expenditure varied from zero to $5 \%$ of the national income from forestry and forest products (Burley and Salleh 1985). Where appropriate cost-benefit analyses have been undertaken forestry research has commonly been found to be financially beneficial. There is still a need to develop techniques for quantifying the benefits of some types and topics of research, particularly institutional and sociological but also on such fundamental scientific topics as the link between trees and climate at the global scale.

Similarly there are still gaps in the methodology of appraising research quality for both scientists and managers. Criteria of excellence vary between topics, locations, institutions and political environments but there are clear indications of the incentives that motivate individual scientists. The financier of research (public tax-payer, government policy-maker or industrial leader) in seeking value for money should attempt to provide these motivations. However, the over-riding factor in research is its relevance and applicability to the final user of the results and the beneficiary of the products and services that trees and forests provide.

\section{The International Union of Forestry Research Organizations}

The International Union of Forestry Research Organizations (IUFRO) is an international, non-governmental organization of some 600 member institutions with 15000 scientists in 105 countries. It comprises an international Council, a President and Executive Board, six scientific Divisions, one Special Programme for Developing Countries and a Task Force on Air Pollution. The Divisions comprise several Subject Groups each containing many Working Parties. Project Groups study topics of interdivisional interest. IUFRO operates primarily through the scientific activities of the Working Parties of scientists addressing common species or problems. It is one of the oldest international organizations and will celebrate its centennial in 1992; throughout its history IUFRO has initiated and enhanced international collaboration and was the first organization to establish networks of research.

Clearly IUFRO cannot address all the questions of motivation but it does contribute to scientific excellence through: 1. the cost-effectivenss of networks

2. sharing of scientific information and materials and consequent reduction of unnecessary research duplication

3. establishment of international standards (e.g. for measurement)

4. training young scientists, particularly from less developed countries

5. promoting awareness of the activities of other international organizations
6. promoting the image of forestry and forest research in international and national arenas

7. identifying research needs, opportunities and institutional or individual capability

8. general international and inter-institutional collaboration and goodwill

Canada is very active in IUFRO with 34 member institutions, 30 scientists as officers at various levels from an Executive Board member to Working Party Co-Chairs, 12 meetings in the country since 1987 , and the quinquennial Congress in 1990.

\section{Further Reading}

Bengston, D.N. 1990. Researcher incentives in public forestry institutions. In: The management of large-scale forestry research programs and projects (A.L. Lundgren, ed.). Proc. Mtg. IUFRO S6.06, Farnham, England, 1989. USDA Forest Service Gen. Tech. Rept. NE-130, 135-145.

Brand, D.G. 1990. Advances in Canadian forest research: an introduction. Can. J. For. Res. 20: 373-374.

Buckman, R.E. 1990. The role of research in tropical forestry. Unasylva 162, 41: 39-43.

Burley, J. 1985. Forestry research networks. In: Increasing productivity of multipurpose species (Burley, J. and Stewart, J.L., eds.). Proc. IUFRO Plan. Wksp. for Asia on For. Res. and Technol. Transfer, Kandy, Sri Lanka. IUFRO, Vienna, Austria, 27-36.

Burley, J. 1987. International forestry research networks - objectives, problems and management. Unasylva 39 (3/4): 67-73.

Burley, J. 1989. Options for forestry research networking. In: The management of large-scale forestry research programs and projects (A.L. Lundgren, ed.). Proc. Mtg. IUFRO S6.06, Farnham, England, 1989. USDA Forest Service Gen. Tech. Rept. NE-130, 185-199.

Burley, J. and Salleh, M.N. 1985. Investment in forestry research. In: Proc. 12th Commonw. For. Conf. Victoria, B.C. Canada, 124-133.

FAO. 1979. Tropical forest research priorities. FAO, Rome, Italy. Gregersen, H.M., Lundgren, A.L. and Bengston, D.N. 1990. Planning and managing forestry research: guidelines for managers. FAO For. Pap. 96, 181p. FAO, Rome, Italy.

ITFFR. 1988. A global research strategy for tropical forestry. Report of an international task force on forestry research. Sponsored by Rockefeller Foundation, UNDP, World Bank and FAO, 88p.

National Research Council. 1990. Forestry research - a mandate for change. Comm. on For. Res. Nat. Acad. Sci. Press, Washington, DC, USA 84p.

O'Loughlin, C. 1990. Forest research - coping with change. N.Z. For., May, 16-19.

Oxford Forestry Institute. 1986. Sub-Saharan African Agricultural Review for World Bank, 1986. Forestry research in east Africa. Tropical Forestry Paper 19, Oxford Forestry Institute, Oxford, England, 58p. and 27 annexes.

Plucknett, D.L. and Smith, N.J.H. 1984. Networking in international agricultural research. Sci. 225: 989-993.

World Bank. 1985. Forestry research in the Sahel countries. World Bank, Washington, DC, USA.

World Bank and FAO. 1981. Forestry research needs in developing countries - time for a reappraisal? Special Paper, 17th IUFRO Congress, Kyoto, Japan. 


\section{Silviculture by Design Joint Technical Session of the Ecology, Hydrology, and Silviculture Working Groups. 22 August 1990, Fredericton, New-Brunswick}

Over the past decades, the practice of forestry has been marked by a series of dramatic changes. Rising labour costs and a drive for efficiency led to the large scale mechanization of forest harvesting in the sixties and seventies. Rising concerns with poor stocking on cutover sites led to large scale reforestation efforts in the seventies, and especially the eighties. Rising international competition, environmental concerns, and shrinking land base seems to open the way to large scale silvicultural efforts in new and established stands in the nineties.

This session was an attempt to underline two aspects of silviculture. The first, as reflected by the title of the session, was that silvicultural thought should be incorporated into all forestry-related activities, creating what we called "silviculture by design". The lack of such planning would lead to "silviculture by default" which could have smaller immediate costs, but much higher long-term costs in terms of mortality, growth reductions, or susceptibility to insects and diseases.

The second aspect was that silviculture should be based on understanding the interactions between the tree and its environment. The talks focussed on two environmental parameters, energy (light) and moisture, that we can manage through silvicultural operations, and the role these parameters played in soil fertility, hardwood and softwood reproduction and growth, and wetland drainage.

Pierre Y. Bernier, Hydrology WG Ian Corns, Ecology WG Jim Richardson, Silviculture WG

\section{Temperature, Moisture and Soil Fertility$$
\text { H.H. Krause }{ }^{1}
$$

\begin{abstract}
The fertility of forest soils basically depends on the mineralogical composition and texture of the parent material, and it is influenced by current soil moisture and temperature regimes. Soil moisture influences the rate of chemical weathering as well as organic matter decomposition. It further acts as the medium for nutrient transport within the soil and from soil to plant. The effect of temperature on fertility is most strongly reflected by the rate of litter decomposition and recycling of nutrients. For example, the time required for a complete turnover of organic matter (residence time) in the forest floor may be less than one year in tropical forests, but may vary from 10 to more than
\end{abstract}

100 years in Canadian forest regions. These contrasts typically reflect high and low nutrient use efficiency in forest ecosystems.

Under comparable climatic conditions and soil mineral potential, the residence time of forest floor organic matter further varies with cover type, stand density and age. This is due to the effect of the latter on soil temperature and moisture regimes, and the differences in litter decomposability which is a characteristic of species and age. These relationships present the basis for optimizing nutrient use efficiency through selected silvicultural intervention, and for improving thereby stand productivity.

The literature contains numerous accounts of improvements in available nutrient supply and cycling following reduction in stand density by commercial and precommercial thinning. Soil fertility and nutrient cycling is renewed after clearcutting on cold soils with conifer cover. Reduction in rotation age and prescribed burning for site preparation are additional means to increase nutrient use efficiency on extreme sites. In contrast, a flush of nutrients, leading to losses from the site, can be expected after clearcutting on warm soils supporting species that form readily decomposable litter. It is under these conditions that harvesting systems other than clearcutting may be considered. Observations are limited and opinions differ about the effects resulting from change of species. From existing information, it can be deduced that soil fertility and nutrient cycling will be impaired in time where species with readily decomposable litter are replaced by species of low litter decomposability. An example is the replacement of hardwoods by black spruce.

Although conventional silvicultural methods offer a certain potential for increased nutrient use efficiency, it should be realized that acute nutrient deficiencies cannot be eliminated without the use of fertilizers, and that maximum production can rarely be achieved at most sites with indigenous nutrient supplies only.

\section{Energy and Moisture - Wetland Silviculture R.L. Rothwell 1}

\section{Abstract}

The theme of this session is 'Silviculture by Design', which can be defined as the purposive use of our experience and knowledge to achieve well planned silviculture, in contrast to silviculture by default where treatments are not well planned or are constrained by external forces. Peatland drainage is a good example of 'Silviculture by Design', as it is based on extensive experience and scientific investigation with the primary objective to improve tree growth by removing excess water from surface soils. Drainage lowers the water table, usually by $30-40 \mathrm{~cm}$, which reduces and changes the spatial patterns of soil moisture. Water contents in a drained Alberta peatland were greater by $5-10 \%$ by volume along ditch edges than at interior locations because of greater subsidence along ditches which increased peat

\footnotetext{
'Dept. Forest Science, University of Alberta, Edmonton, Alberta.
} 
water retention. The removal of water and greater bulk density induced by subsidence interacted to change the thermal properties of peat, making soil temperatures greater on drained than undrained peatlands. Maximum temperatures on the drained area were $20-21^{\circ} \mathrm{C}$ in midsummer, $3-4^{\circ} \mathrm{C}$ warmer than the undrained site. Most of the warming was restricted to surface layers, as heat conduction to deeper layers was reduced by the drained surface layers which acted as an insulating medium.

Tree growth response on drained areas is usually delayed for a few years after drainage until trees have adjusted to the new soil environment. Initial responses will usually be increased rooting following the lowering of the water table. Following drainage increased rates of photosynthesis and improved water relations can be expected on drained sites. Studies in Alberta have shown a strong correlation between fine root biomass and water table depth; and earlier and higher rates of photosynthesis on drained sites. Increases in radial and height growth were observed on drained Alberta peatlands 5-6 years after drainage. Tree ring growth increased almost linearly, reaching a maximum 13-19 years after drainage.

Peatland drainage provides a good example of 'Silviculture by Design' where our experience and knowledge is purposely used to change the energy and moisture conditions of a site to improve tree growth.

\section{Hardwood Regeneration and Growth Responses Under Two Systems - Clearcutting and Selection J.C. Lees ${ }^{1}$}

\begin{abstract}
After clearcutting in mixed northern hardwoods, dramatic changes in light and moisture produce a surge in regeneration and growth. Later in the rotation, activity, other than crop tree growth, diminishes. After harvest cutting under the selection system, no less dramatic changes occur, but they may be confined only to the area occupied by a single tree or a group of trees. Over the selection forest as a whole this activity never diminishes.

Some examples from Maritimes experience are discussed.

C.I.F. Working group technical session, "Silviculture by design.," Fredericton August 22, 1990.
\end{abstract}

${ }^{1}$ Maritimes Forestry Centre, Forestry Canada, Fredericton, N.B.

\section{Energy, Moisture and Coniferous Reforestation R.L. Fleming 1}

\section{Abstract}

This presentation addressed biophysical constraints to coniferous reforestation in Canada. The physical environment following clearcutting was first described and evaluated vis-a-vis its impact on conifer seedlings. Four major constraints common to many upland cutovers were identified: low soil temperatures, low surface temperatures, nearsurface moisture deficits and root zone moisture deficits. Each of these factors was then considered in terms of microclimatic processes, silvicultural prescriptions and seedling response using examples from British Columbia and Ontario.

Temperature limitations were addressed by considering the surface energy balance and soil thermal properties. Warmer soil temperatures can be obtained by eliminating surface shading and by removing surface organic horizons to increase the soil thermal admittance and thermal diffusivity. Increasing the thermal admittance will also moderate minimum surface temperatures and reduce frost damage potential. Another strategy in this regard is to reduce the seedling sky view factor (the fraction of surface radiation emitted to the sky) by modified harvesting. Long wave radiation emitted from adjacent stands can reduce radiation frost susceptibility.

Soil moisture was addressed by considering the soil water balance. Root zone moisture deficits largely result from transpiration by competing vegetation rather than from excessive surface evaporation. Vegetation removal by chemical or mechanical means is effective in improving moisture availability. To ensure adequate near-surface soil moisture for young germinants provision of seedbeds with favorable hydraulic properties (i.e., near the mineral soil-humus interface) is a requisite. Seed shelters can be used to promote germination and establishment on drier sites. Within the shelter the atmospheric demand for moisture is reduced and nearsurface soil water reserves are conserved.

Proper identification of limiting physical factors, interactions between different factors and treatment size considerations related to lateral flow were also discussed.

'Forestry Canada, Ontario Region 